\title{
Geology, Hydrology, and Ground-Water Flow near the Akron Municipal Well, Erie County, New York
}

By William M. Kappel, and Todd S. Miller

U.S. GEOLOGICAL SURVEY

Water-Resources Investigations Report 96-4193

Prepared in cooperation with the

ERIE COUNTY DEPARTMENT OF ENVIRONMENT AND PLANNING 


\section{U.S. DEPARTMENT OF THE INTERIOR \\ Bruce Babbitt, Secretary}

U.S. GEOLOGICAL SURVEY

Gordon P. Eaton, Director

For additional information write to:

Subdistrict Chief U.S. Geological Survey 903 Hanshaw Road

Ithaca, NY 14850-1573
Copies of this report can be be purchased from:

U.S. Geological Survey Branch of Information Services Box 25286

Denver, CO 80225-0286 


\section{CONTENTS}

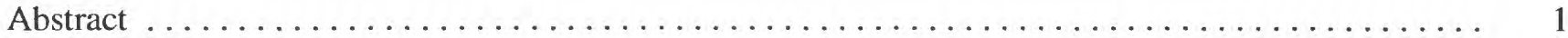

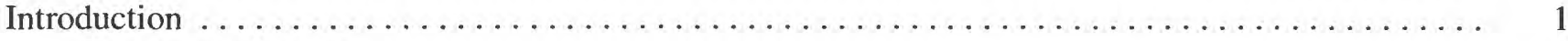

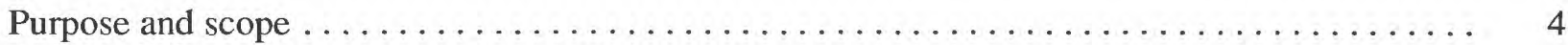

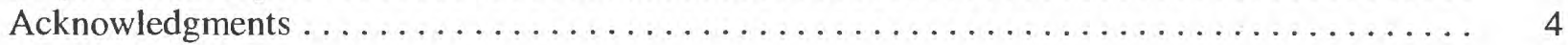

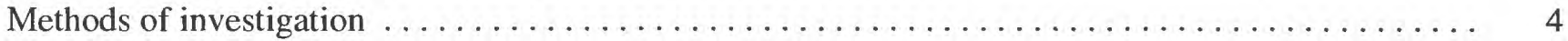

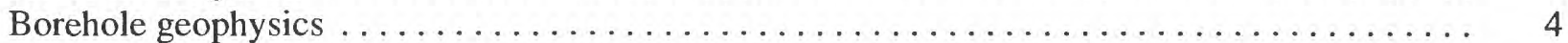

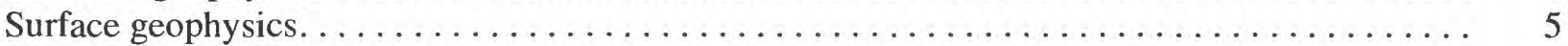

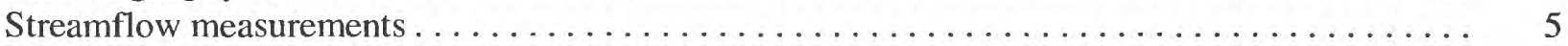

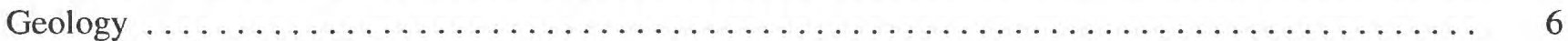

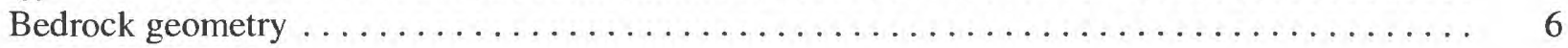

Bedrock lithology. . . . . . . . . . . . . . . 6

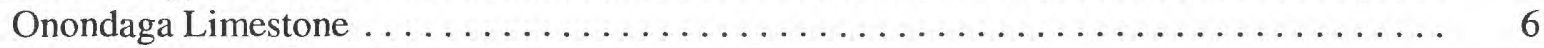

Akron Dolomite-Bertie Limestone . . . . . . . . . . . . . . . . . . . 9

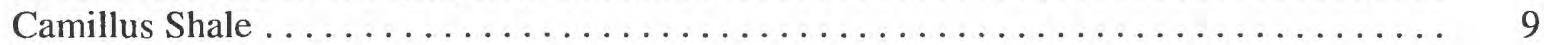

Hydrology . . . . . . . . . . . . . . . . . . . . . . . . . . 9

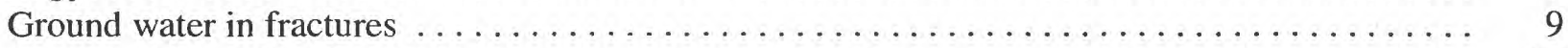

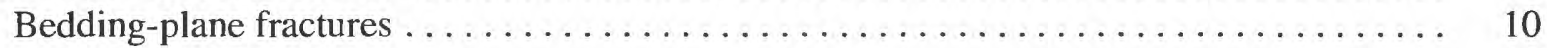

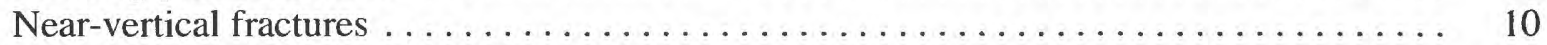

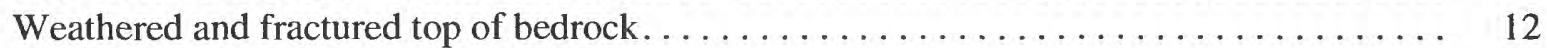

Well-yield characteristics. . . . . . . . . . . . . . . 13

Ground-water quality . . . . . . . . . . . . . . . . 13

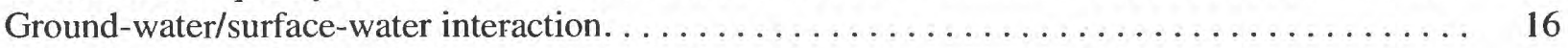

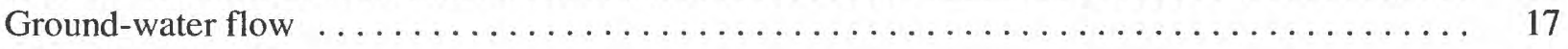

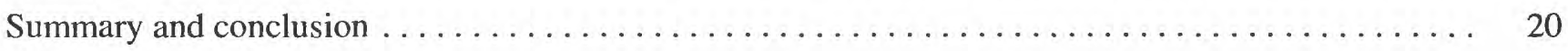

References cited ...................................... 20

\section{FIGURES}

1. Map showing principal geographic features of Erie County, N.Y., including unconsolidated and bedrock aquifers and location of study areas . . . . . . . . . . . . . . . . . . .

2. Map showing principal geographic features near Akron study area in eastern Erie County, N.Y., including Akron water-supply reservoir and municipal well, surficial bedrock units, and streamflowmeasurement sites. . . . . . . . . . . . . . . . . . . . . . . . . . .

3. Schematic diagram showing square-array resistivity layout, size of squares, and rotation of

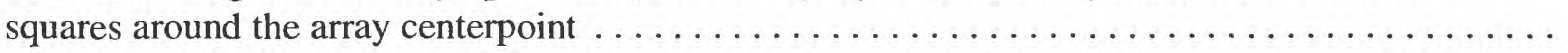

4. North-south geologic section along Crittenden/Scotland Roads near Akron, N.Y., area showing locations of wells with gamma-ray profiles and the contacts between major bedrock units.......

5. Map showing locations of all wells used for data collection in Akron study area Erie County, N.Y.,

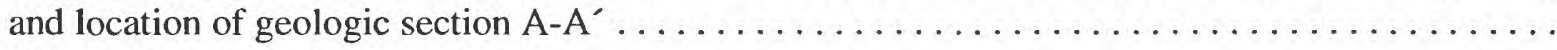

6. Diagrams showing square-array apparent resistivity plotted against azimuth for squares of 46.2, 65.6, 98.2, and 115.8 feet measured near the Village of Akron's municipal well, Erie County, N,Y..... 
FIGURES (continued)

7. Piper diagram showing chemical characteristics of water from Akron municipal well in relation to water from the Onondaga Limestone and unconsolidated deposits in surrounding area as compiled by Miller and Staubitz (1985) . . . . . . . . . . . . .

8. Stiff diagrams showing median anion and cation concentrations in water from Akron municipal well Erie County, N.Y., and reported results from several other aquifers in the Akron area ......

9. North-south geologic section east of Crittenden/Scotland Roads showing ground-water flowpaths and the three major bedrock discharge locations in the Akron study area $\ldots \ldots \ldots \ldots \ldots$

10. Map showing potentiometric-surface altitude in upper bedrock and locations of ground-water divides north and south of Akron municipal well, Erie County, N.Y...............

\section{TABLES}

1. Summary of bedrock units in the Akron study area in eastern Erie County, N.Y............

2. Azimuthal apparent-resistivity measurements collected near the Village of Akron's municipal well field, Erie County, N.Y. . . . . . . . . . . . . . . . . . . . .

3. Ratio of sodium and chloride (by mass) in water from the Akron municipal well, Erie County, N.Y. February 1981 through October $1985 \ldots \ldots \ldots \ldots \ldots \ldots \ldots \ldots \ldots \ldots \ldots \ldots \ldots \ldots \ldots \ldots \ldots \ldots \ldots \ldots \ldots$.

4. Results of streamflow measurements on Murder Creek and selected tributaries, Erie County, N.Y.,

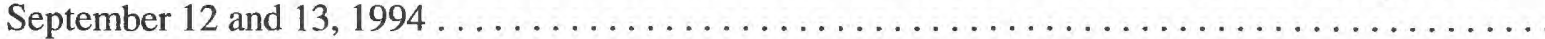




\section{CONVERSION FACTORS, ABBREVIATIONS, AND VERTICAL DATUM}

Multiply

foot ( $\mathrm{ft}$ )

mile (mi)

0.1894

Area

square mile $\left(\mathrm{mi}^{2}\right)$

acre

2.59

0.40483

Flow

cubic foot per second $\left(\mathrm{ft}^{3} / \mathrm{s}\right)$

0.02832

25.4

inch per year (in/yr)

.003785

3.785

0.06309

0.0010515

gallons per day (gal/d)

0.0109267

Volume

cubic feet $\left(\mathrm{ft}^{3}\right)$

cubic yards $\left(\mathrm{yd}^{3}\right)$

0.02832

Temperature

degrees Fahrenheit $\left({ }^{\circ} \mathrm{F}\right)$
${ }^{\circ} \mathrm{C}=5 / 9\left({ }^{\circ} \mathrm{F}-32\right)$

degrees Celsius centimeter

meter

kilometer

meter per kilometer

square kilometer

hectare

cubic meter per second

millimeter per year

cubic meters per day

liters per day

liter per second

liter per second

cubic meter per second per

square kilometer

cubic meters

\section{Specific Conductance \\ microsiemens per centimeter at $25^{\circ}$ Celsius $(\mu \mathrm{S} / \mathrm{cm})$ \\ Equivalent Concentration Terms \\ milligrams per liter $(\mathrm{mg} / \mathrm{L})=$ parts per million \\ micrograms per liter $(\mathrm{ug} / \mathrm{L})=$ parts per billion}

Sea level: In this report, "sea level" refers to the National Geodetic Vertical Datum of 1929—a geodetic datum derived from a general adjustment of the first-order level nets of the United States and Canada, formerly called Sea Level Datum of 1929. 


\title{
Geology, Hydrology, and Ground-Water Flow near the Akron Municipal Well, Erie County, New York
}

\author{
By William M. Kappel and Todd S. Miller
}

\section{Abstract}

The Village of Akron, in northeastern Erie County, N.Y., uses ground water to supplement its surface-water supply, but the yield of ground water and its protection from contamination is of concern. Bedrock wells in the Akron area obtain water from fractures within and below the Onondaga

Limestone. An extensive unconformity and associated bedding-plane fracture at the contact between the Onondaga Limestone and the underlying Akron Dolomite probably is the primary water-bearing zone that contributes water to the municipal watersupply well for Akron. Results of a square-array resistivity survey indicate weakly developed, nearvertical fractures in the Onondaga Limestone that strike along azimuth $075^{\circ}$ in the Akron area; these fractures probably have only a minor role in regional ground-water flow patterns, however.

The major source of recharge to the Onondaga Limestone in the Akron area is precipitation. Streamflow measurements along Murder Creek indicate a downstream increase in ground-water discharge as the creek approaches the Onondaga Escarpment; therefore, little or no infiltration of water from Murder Creek to the Akron municipal well is likely. Chemical analyses of water from this well indicate that most recharge consists of freshwater flowing downdip (southward) from the Onondaga Escarpment area along the contact between the Onondaga Limestone and the Akron Dolomite, but some water also comes from the upper, weathered Onondaga Limestone. The well also receives some brackish water from a deep bedrock source; this water apparently moves updip from the southwest along the Onondaga-Akron bedding-plane fracture.

\section{INTRODUCTION}

The Erie County Department of Environment and Planning is promoting the development of Wellhead Protection strategies for municipal wellfields in the county. In 1994, the U.S. Geological Survey (USGS), in cooperation with the Erie County Department of Environment and Planning, began a 1year study to investigate factors that affect the areas that contribute recharge to wells in four municipalities in Erie County-the Villages of Alden and Akron, and the Towns of Collins and Holland (fig. 1). Municipal wells for Alden, Collins, and Holland tap glacial-drift aquifers, but the Akron municipal well taps the Onondaga Limestone aquifer. Hydrologic data for the three municipalities whose wells tap glacial-drift aquifers are sufficient to construct numerical ground-water flow models that could be used to investigate contributing areas to those wells, but data on the fractured bedrock aquifer in the Akron area are insufficient for model construction.

The Akron Reservoir, in the headwaters of Murder Creek (fig. 2) in the northwestern part of Wyoming County, to the southeast, is a 75-acre impoundment with a safe yield of more than $700,000 \mathrm{gal} / \mathrm{d}$ (Daniel Huff, Superintendent of Public Works, Village of Akron, written commun., 1995). This supply is supplemented by a 70-ft-deep municipal well that is completed in the Onondaga Limestone and can pump as much as $140,000 \mathrm{gal} / \mathrm{d}$. This well is along Crittenden Road, $1 \mathrm{mi}$ southeast of the village (fig. 2).

The Onondaga Limestone is a fractured-bedrock aquifer that has solution-widened openings (Staubitz and Miller, 1987). Most recharge to the aquifer consists of precipitation that infiltrates through fractures at or near the land surface. Water levels in this aquifer typically fluctuate 5 to $10 \mathrm{ft}$ annually, except near a 2.2-mi-long "channel-like depression 


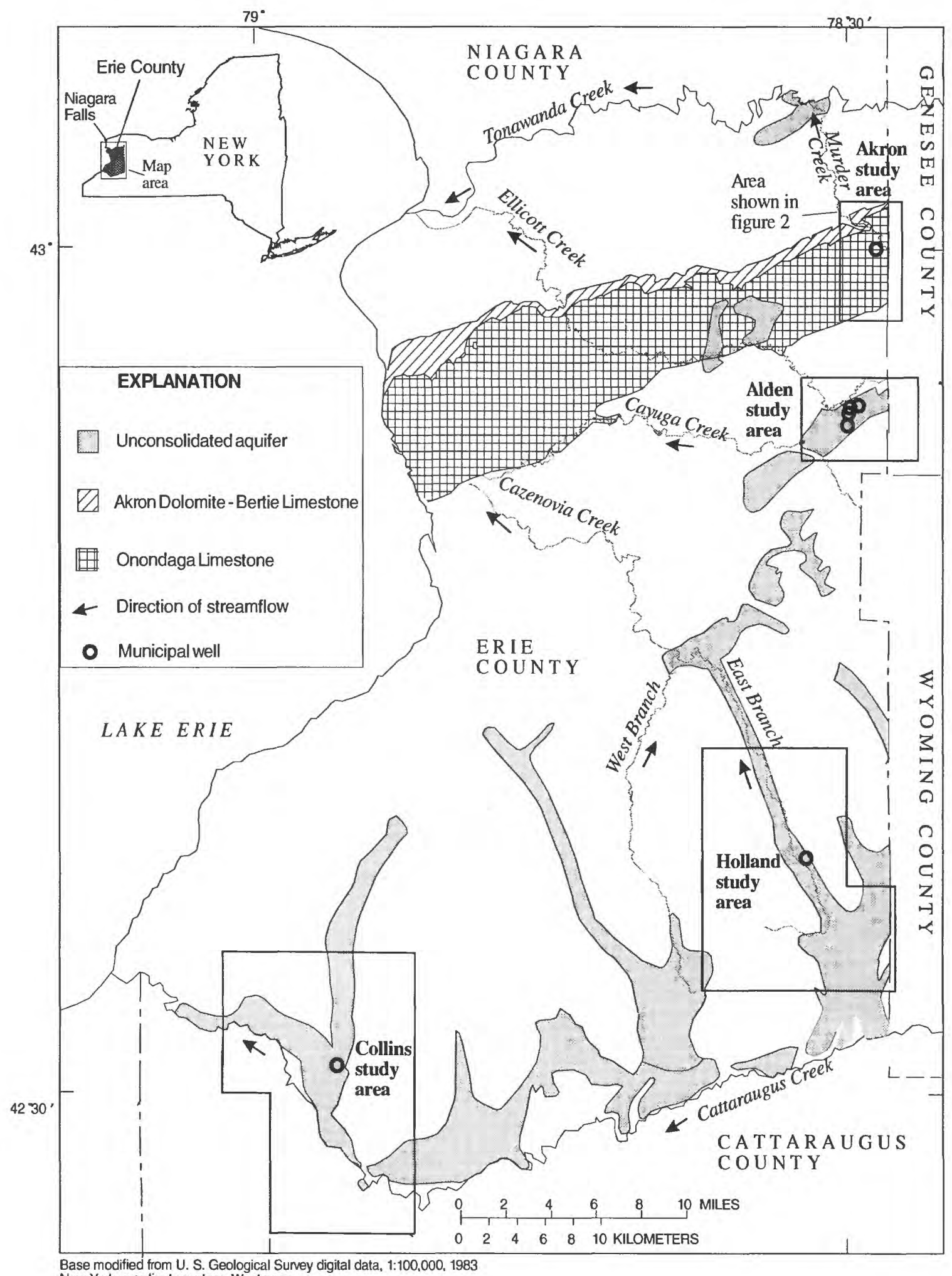

Base modified from U. S. Geological Survey digital data, 1:100,000, 1983 New York coordinate system, West zone

Figure 1. Principal geographic features of Erie County, N.Y., including unconsolidated and bedrock aquifers and location of study areas. 


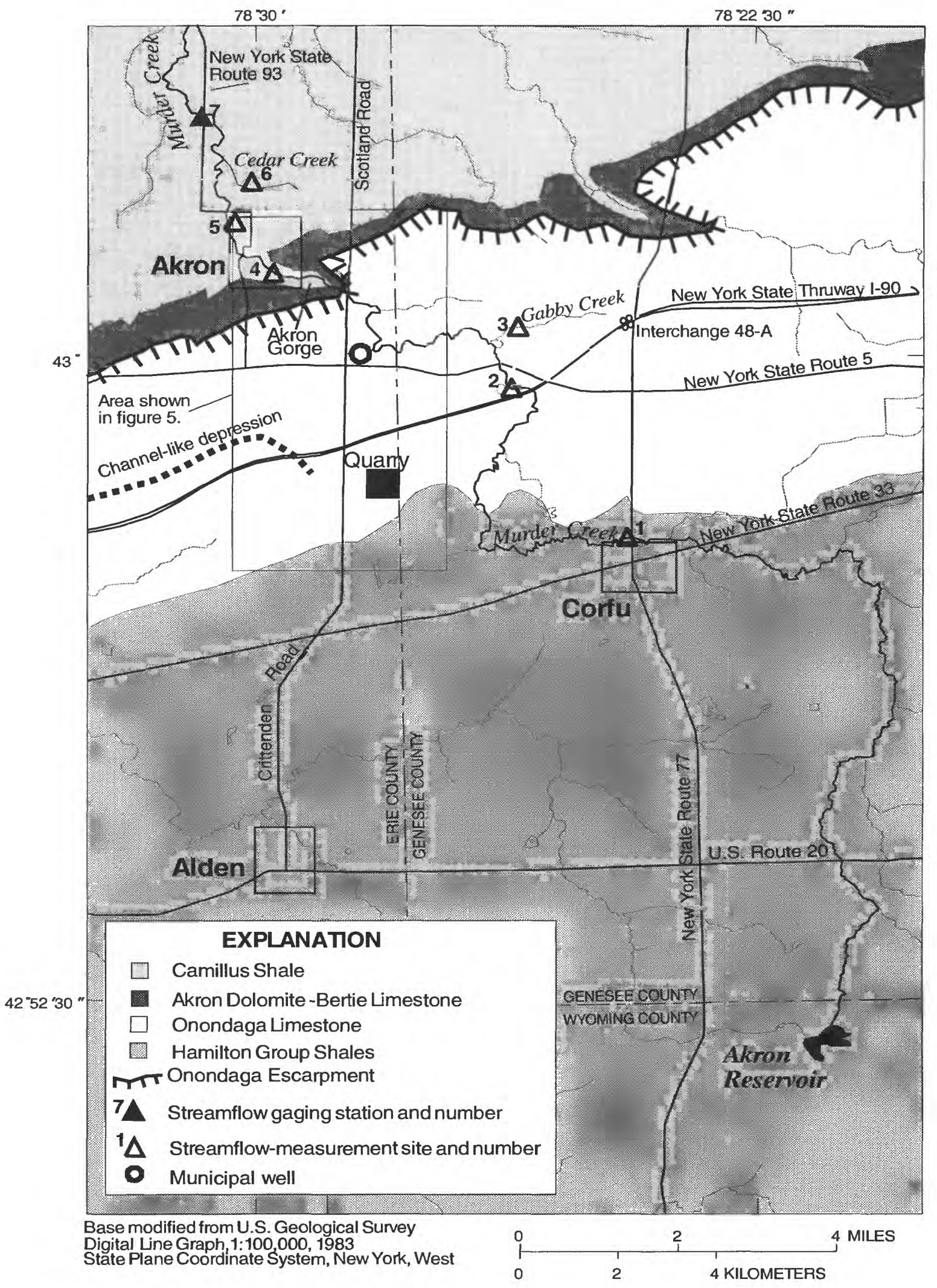

Figure 2. Principal geographic features near Akron study area in eastern Erie County, N.Y., including Akron water-supply reservoir and municipal well, surficial bedrock units, and streamflow-measurement sites. (Location is shown in fig. 1.) 
area" of sinkholes and disappearing streams $2 \mathrm{mi}$ south of Akron (fig. 2), where water-level fluctuations can exceed $40 \mathrm{ft}$ (Staubitz and Miller, 1987). Movement of ground water along the high-angle and bedding-plane fractures are the only pathways for water to move from areas of recharge to areas of discharge in the bedrock, or to wells that supply many of the homes in the Akron area.

Land use in the study area is a mixture of agriculture (dairy farms) and low-density residential. Mining of gypsum deposits in the Camillus Shale north of the Onondaga Escarpment was historically important but ceased in the mid-1970's. Sand and gravel mining and limestone quarrying continue today. Interstate 90 (New York State Thruway) traverses the study area south of the Village of Akron.

\section{Purpose and Scope}

This report (1) defines the geometry of the Onondaga Limestone aquifer and describes the fractured-bedrock flow system, (2) presents maps and geologic sections of the Onondaga Limestone and deeper bedrock units, (3) presents vertical-fractureorientation plots derived from surface geophysical surveys near the municipal well, (4) presents natural gamma-ray borehole geophysical logs of selected wells along Crittenden and Scotland Roads, and (5) presents a conceptualized geologic section indicating ground-water flowpaths to the Akron municipal well.

\section{Acknowledgments}

Spencer Schofield of the Erie County Department of Environment and Planning initiated this study and facilitated communication between Federal, State and local governmental agencies. Daniel Huff, Akron Superintendent of Public Works, and his staff, provided data and field assistance throughout the project. Mark Pearce of U.S. Gypsum Energy Company provided natural-gamma logs of gas wells drilled in the study area, and the owners of County Line Stone Quarry provided access to the quarry and to monitoring wells surrounding the quarry. William Frey, of Frey Well Drilling, provided drilling records of domestic wells near the Akron municipal well.

\section{METHODS OF INVESTIGATION}

Several approaches were used to characterize the geologic and hydrologic conditions in the Akron area:

(1) Borehole- and surface-geophysical techniques were used to evaluate the extent of nearhorizontal bedding-plane fractures and the orientation of near-vertical fractures in the bedrock;

(2) supplemental borehole geophysical logs (natural gamma-ray emission) from nearby natural-gas wells were used to define the regional bedrock stratigraphy;

(3) streamflow measurements were made to identify gaining or losing reaches of Murder Creek and selected tributaries; and

(4) drilling logs and water-quality data, supplied by the Village of Akron, were analyzed to determine the source and chemical quality of ground water in the vicinity of the municipal-well.

\section{Borehole Geophysics}

Borehole geophysical methods are used in ground-water investigations to obtain information on well construction, rock lithology, location and orientation of fractures and transmissive zones, and chemical quality of ground water. The geophysical methods entail use of logging tools that are lowered into a well and transmit electronic signals to aboveground recording and processing equipment.

Geophysical logging methods and their application to ground-water investigations are described in detail by Keys (1990). The most useful types of geophysical logs collected in this study were the following:

Caliper logs-Caliper logs record borehole diameter. Changes in borehole diameter are related to well construction, such as casing or drilling-bit size, and the occurrence of fractures or caving along the borehole wall.

Gamma logs-Gamma logs record the amount of natural gamma radiation emitted by rocks surrounding the borehole. The most significant naturally occurring sources of gamma radiation are clay- and shale-bearing rocks, which are easily distinguished from limestone and dolomite, which emit relatively low gamma radiation. 
Temperature logs-Temperature logs record the temperature of water in the borehole and are useful for delineating water-bearing zones and identifying vertical flow in the borehole. Borehole flow between zones can be indicated by changes in the temperature gradient of the well

Flow-meter logs-Flow-meter logs record the direction and rate of vertical flow in the borehole. Borehole-flow rates can be calculated from downhole-velocity measurements and the borehole diameter recorded by the caliper log.

Video-camera logs-Video-camera logs record a color image of the borehole. Well construction, lithology, fractures, water level, cascading water from above the water level, and changes in borehole water quality with depth (chemical precipitates, suspended particles, and gas) can often be seen in the video record.

\section{Surface Geophysics}

Surface geophysical methods are used in ground-water investigations to obtain information on physical properties and structure of the bedrock below land surface. The method used in this study was azimuthal square-array direct current (dc) resistivity, where resistivity soundings were used to detect the orientation of near-vertical fractures in bedrock. This method is described in detail by Lane and others (1995).

Square-array resistivity soundings were used in an open field about $300 \mathrm{ft}$ east of the municipal well to detect the strike of near-vertical fractures in bedrock. Techniques for analyzing the apparent resistivity data collected by the square-array method have been developed by Habberjam (1972) and been tested and used successfully at a crystalline rock site at Mirror Lake, N.H., by Lane and others (1995).

The resistivity measurement is assigned to the centerpoint of the square array (fig. 3), which is expanded and rotated about the centerpoint; eight squares measuring $11.6 \mathrm{ft}, 16.4 \mathrm{ft}, 23.3 \mathrm{ft}, 32.8 \mathrm{ft}$, $46.2 \mathrm{ft}, 65.6 \mathrm{ft}, 92.8 \mathrm{ft}$, and $115.8 \mathrm{ft}$ constitute one set of measurements. The squares are positioned such that increasing volumes (depths) of earth materials are penetrated as the square is expanded. The measurements for one set of eight squares are collected; then the square is rotated 15 degrees and another set of eight expanding-square measurements is taken. Six sets of expanding-square measurements (fig. 3) are then plotted on polar coordinate paper to indicate the orientation of any near-vertical fractures.

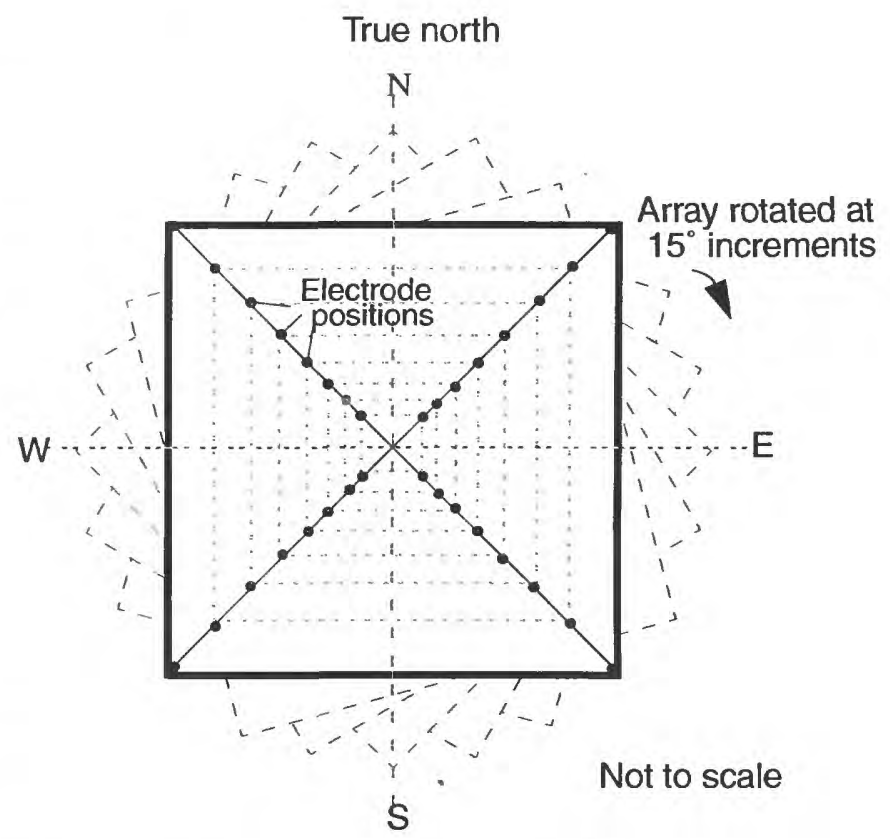

Figure 3. Schematic diagram showing square-array resistivity layout, size of squares (11.6 to 115.8 feet), and rotation of squares (in 15-degree increments) around the array centerpoint.

\section{Streamflow Measurements}

Ten sites along Murder Creek and its tributaries were chosen for streamflow measurements (to calculate gains or losses) by methods described in Rantz and others (1982), but only six locations (fig. 2) had flowing water during the autumn low-flow period of September 1994. The drainage area upstream from each measurement site was determined from topographic maps, and changes in streamflow from site to site were compared on a volume per unitdrainage-area basis to indicate relative gains or losses in streamflow between measurement locations. 


\section{GEOLOGY}

Bedrock units of upper Silurian to lower Devonian age strike roughly east-west and dip to the south-southwest at 40 to $50 \mathrm{ft} / \mathrm{mi}$ (Staubitz, and Miller, 1987). The uppermost bedrock unit in the study area is the Onondaga Limestone, which is overlain by till in the north and by till and lacustrine deposits of variable thickness in the south. Glacialdrift deposits near the Onondaga Escarpment in the north (fig. 2) are thin ( 0 to $5 \mathrm{ft}$ thick) but thicken to the south, where they are generally more than $25 \mathrm{ft}$ thick.

\section{Bedrock Geometry}

The geometry of the bedrock units was defined though an analysis of geophysical logs obtained by the USGS and logs of natural-gas wells in the Akron area obtained by U.S. Gypsum Energy Company. Natural-gamma ray logs were used to determine lithologic boundaries of major bedrock units. The major lithologic contacts that are readily apparent in natural gamma-ray logs are between (1) the bottom of the Onondaga Limestone and the top of the Akron Dolomite, (2) the bottom of the Akron Dolomite and the top of the Bertie Limestone and, (3) the bottom of the Bertie Limestone and the top of the Camillus Shale (fig. 4). This three-peak gamma signature was observed on all gamma-ray logs from boreholes that penetrated the Akron Dolomite through Camillus Shale bedrock sequence-the peaks at the top and bottom of the Akron Dolomite are related to thin, shaley beds (Cassa, 1980) and sometimes to naturally occurring organic (petroliferous) material (Dunn, 1992), whereas the peak at the Bertie LimestoneCamillus Shale contact reflects the lithologic change from gamma-poor limestone to gamma-rich shale. The geophysical logs for test holes and wells drilled along Crittenden Road show that the dip and relative thickness of the bedrock units in this area are fairly uniform (fig. 4).

The strike and dip of the bedrock were estimated by applying the three-point method of Compton (1985) to the altitudes of gamma-ray peaks at the contact between the Onondaga Limestone and Akron Dolomite and between the Bertie Limestone and Camillus Shale. The six wells that were used to determine strike and dip of the bedrock were along Crittenden Road and New York State Route 5 (fig. 5). The Onondaga/Akron contact strikes $S 63^{\circ} \mathrm{E}$ and dips $37 \mathrm{ft} / \mathrm{mi}$ to the southwest. The Bertie Limestone and Camillus Shale contact has a similar strike at $\mathrm{S} 65^{\circ} \mathrm{E}$ and dips $38 \mathrm{ft} / \mathrm{mi}$ to the southwest; these numbers are similar to those reported by Staubitz and Miller (1987). The average dip of the bedrock along the geologic section that parallels Crittenden and Scotland Roads (A- $\mathrm{A}^{\prime}$ in fig. 5) is $33.5 \mathrm{ft} / \mathrm{mi}$.

\section{Bedrock Lithology}

The lowest (oldest) bedrock unit in the Akron area is the Camillus Shale of upper Silurian age, which underlies the Akron Dolomite and Bertie Limestone units of upper Silurian age (table 1). The Akron-Bertie unit is unconformably overlain by the Onondaga Limestone of lower Devonian age. (An unconformity is an erosional surface on which sediments were deposited and then eroded away in the geologic past and now represents an area where units of the regional bedrock sequence are missing.) In the southern part of the study area, the Onondaga Limestone is overlain by the lower part of the Hamilton Group shales of lower Devonian age (fig. 4), whereas in the central and northern parts of the study area, the Onondaga is at or near land surface. The underlying Akron-Bertie unit is exposed along the base of the Onondaga Escarpment and within the Akron Gorge (fig. 2) just south of the Village of Akron. The thickness and erosion-resistant nature of the Onondaga Limestone and underlying Akron Dolomite-Bertie Limestone unit are the reason for the east-west trending Onondaga Escarpment at the northern extent of the study area. North of the escarpment the Camillus Shale is at or near the land surface.

\section{Onondaga Limestone}

The Onondaga Limestone is a massive, argillaceous to cherty limestone that is about $140 \mathrm{ft}$ thick where all members are present. The upper part of the Onondaga Limestone (Seneca and Moorehouse members [95 $\mathrm{ft}$ thick], table 1) is fairly massive but prone to dissolution and the development of karstlike solution features. The Clarence member ( $40 \mathrm{ft}$ thick) can be as much as 75 percent chert within the limestone matrix and is massive and competent; dissolution is limited by the high chert content. The lower Edgecliff member ( $5 \mathrm{ft}$ thick) is less cherty than the Clarence member and locally contains dissolution features. 


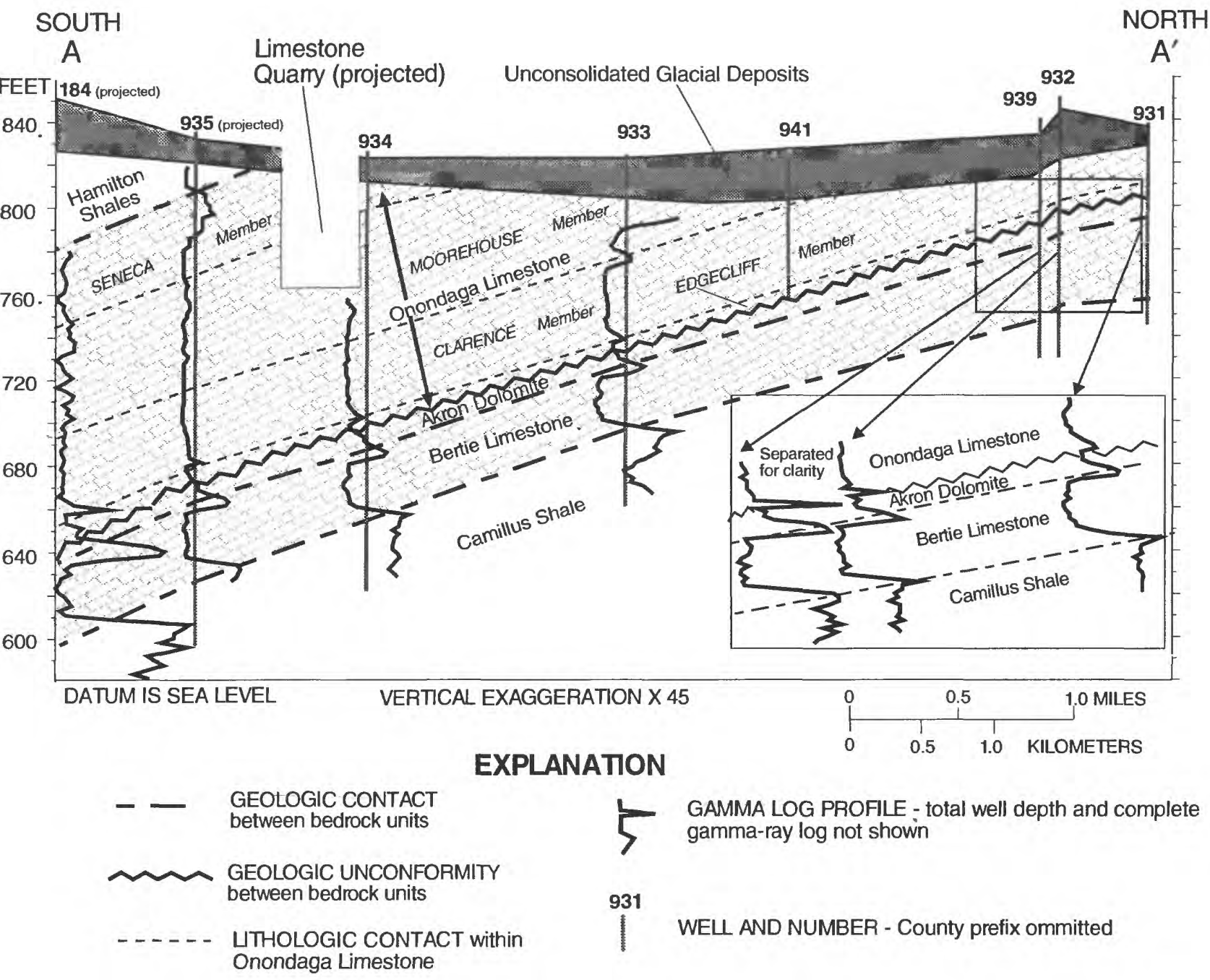

Figure 4. North-south geologic section along Crittenden/Scotland Roads near Akron, N.Y., showing locations of. wells with gamma-ray profiles and the contacts between major bedrock units. (Location of section is shown in fig. 5.)

In the northern part of the study area, the cherty Clarence member is the upper bedrock unit and is typically less than $20 \mathrm{ft}$ thick near the escarpment, where the Seneca and Moorehouse members have been removed by glaciation and erosion. The Onondaga Limestone thickens to the south, where it reaches its full thickness near the County Line Stone quarry (fig. 4).

In the southern half of the study area (south of New York State Route 5 and generally west of Crittenden Road), the Seneca and Moorehouse members of the Onondaga form the upper bedrock unit and have poorly to moderately developed karst features indicative of limestone dissolution. A series of sinkholes southwest of the study area can be seen on topographic maps, and Staubitz and Miller (1987) reported disappearing streams and solution-widened joints in a "channel-like depression area" within the Onondaga Limestone (fig. 2). Widespread water-level declines were reported in and near this area after a stream was diverted away from a series of sinkholes along its eastern end in 1981. 


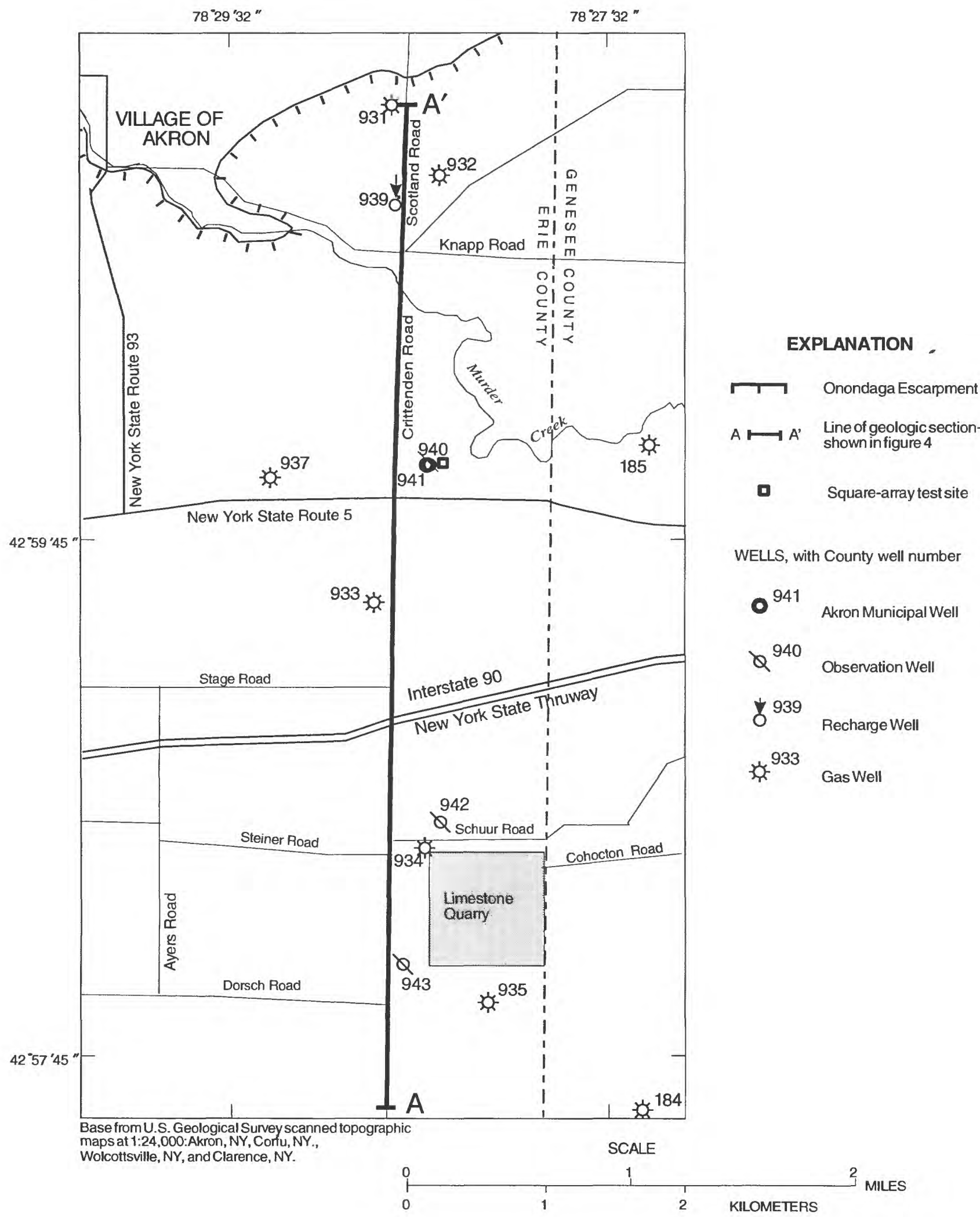

Figure 5. Locations of all wells used for data collection in Akron study area Erie County, N.Y. and location of geologic section $A-A^{\prime}$ (Geologic section is shown in fig. 4.) 
Table 1. Summary of bedrock units in the Akron study area in eastern Erie County. N.Y. [Modified from Staubitz and Miller, 1987.]

\begin{tabular}{|c|c|c|c|c|}
\hline Period & Formation & Member & $\begin{array}{l}\text { Thickness } \\
\text { (feet) }\end{array}$ & Description \\
\hline \multirow{4}{*}{$\begin{array}{l}D \\
e \\
v \\
o \\
n \\
i \\
a \\
n\end{array}$} & \multirow{4}{*}{$\begin{array}{l}\text { Onondaga } \\
\text { Limestone }\end{array}$} & Seneca & 40 & $\begin{array}{l}\text { Olive-gray, massive bedded limestone, contains abundant dark } \\
\text { nodular chert ( } 5 \text { to } 25 \text { percent) }\end{array}$ \\
\hline & & $\begin{array}{l}\text { Moore- } \\
\text { house }\end{array}$ & 55 & $\begin{array}{l}\text { Olive-gray to light olive-gray, fine-grained, massive bedded lime- } \\
\text { stone, contains abundant dark nodular chert ( } 5 \text { to } 50 \text { percent) }\end{array}$ \\
\hline & & Clarence & 40 & $\begin{array}{l}\text { Olive-gray, fine-grained, massive bedded limestone, contains } \\
\text { extremely abundant dark nodular chert ( } 25 \text { to } 75 \text { percent) }\end{array}$ \\
\hline & & Edgecliff & 5 & $\begin{array}{l}\text { Light gray, coarsely crystalline, massive bedded limestone, and } \\
\text { some nodular chert ( } 5 \text { to } 25 \text { percent) }\end{array}$ \\
\hline \multicolumn{5}{|c|}{-------- Unconformity $\quad--------$} \\
\hline \multirow{3}{*}{$\begin{array}{l}\text { S } \\
\mathrm{i} \\
\mathrm{I} \\
\mathrm{u} \\
\mathrm{r} \\
\mathrm{i} \\
\mathrm{a} \\
\mathrm{n}\end{array}$} & $\begin{array}{c}\text { Akron } \\
\text { Dolomite }\end{array}$ & & 8 & $\begin{array}{l}\text { Greenish-gray to light buff, mottled and banded fine-grained } \\
\text { dolomite }\end{array}$ \\
\hline & $\begin{array}{c}\text { Bertie } \\
\text { Limestone }\end{array}$ & & 55 & $\begin{array}{l}\text { Gray to dark gray, thin to medium bedded, fine-grained dolomite, } \\
\text { dolomitic limestone and shaley limestone }\end{array}$ \\
\hline & $\begin{array}{l}\text { Camillus } \\
\text { Shale }\end{array}$ & & 400 & $\begin{array}{l}\text { Gray to brownish gray, thin to massive bedding, shale with some } \\
\text { interbedded limestone and dolomite, contains abundant gypsum } \\
\text { with beds up to } 5 \mathrm{ft} \text { thick }\end{array}$ \\
\hline
\end{tabular}

\section{Akron Dolomite - Bertie Limestone unit}

Underlying the Onondaga Limestone are the Akron Dolomite and Bertie Limestone, which together are about $60 \mathrm{ft}$ thick (fig. 4). This unit consists of limestone and shaley to nearly pure dolomite mixed with some dolomitic limestone. The Akron-Bertie unit was mined for water-lime (cement) in the 1800's in the Akron Gorge, in the village of Akron, and elsewhere along the Onondaga Escarpment.

\section{Camillus Shale}

The 400-ft thick Camillus Shale lies below the Akron-Bertie unit south of the Onondaga Escarpment (north of the escarpment, the Camillus is exposed near land surface). The upper part of the Camillus consists of beds of limestone, dolomite, and beds of gypsum that were mined near the Akron area. The last Akron-area mine closed in 1975. The upper part of the Camillus Shale is highly permeable where weathering and dissolution of gypsum and other mineral salts takes place.

\section{HYDROLOGY}

Ground water in bedrock is recharged by precipitation that falls directly on bedrock exposures near the Onondaga Escarpment and by infiltration of precipitation through the unconsolidated deposits that overlie the bedrock. The Onondaga Limestone has little primary permeability, therefore, ground-water flows through fractures. Secondary permeability (fracture flow) is enhanced by dissolution of calcium carbonate, gypsum, and other soluble minerals. The chemical quality of ground water generally results from interactions between water and minerals as water moves through unconsolidated deposits and bedrock fractures to points of discharge.

\section{Ground Water in Fractures}

The primary conduits for ground-water flow in the Akron area are fractures in the Onondaga Limestone. Fracture characteristics that affect ground-water flow include orientation, connectivity, aperture (size of fracture opening), roughness, length, 
and spatial distribution. Gently dipping bedding-plane fractures were observed to be the major water-bearing zones in bedrock in this study area; steeply dipping (near-vertical) fractures are secondary flowpaths, especially near land surface, where aperture widening through physical and chemical weathering (solutioning) can increase ground-water flow in bedrock (Yager and Kappel, 1987).

\section{Bedding-plane Fractures}

Borehole-camera and flowmeter logs of wells along Crittenden Road and Scotland Road were recorded at four sites to indicate the water-bearing characteristics of bedding-plane fractures in the Onondaga Limestone. (Well locations are shown in fig. 5.)

Well 940 - Borehole logs from this 52-ft-deep monitoring well, about $25 \mathrm{ft}$ from the Akron municipal well (well 941), indicated no significant bedding-plane fractures, and no vertical flow was detected in the borehole while the municipal well was pumped. The municipal well is $70 \mathrm{ft}$ deep, about $20 \mathrm{ft}$ deeper than the monitoring well, and the major fracture(s) that transmit water to the municipal well are between the 52- and 70$\mathrm{ft}$ depth. The likely major bedding plane at this depth is at the regional unconformity between the Onondaga Limestone and the Akron Dolomite (table 1).

Well 939 - This domestic dewatering well, about 1 mi north of the municipal well and just northeast of the Akron gorge, is drilled through the Onondaga Limestone into the upper part of the Camillus Shale. The borehole camera log indicates that ground water flows into the borehole at the Onondaga/Akron contact and flows down to a standing water level in the upper Camillus Shale. The homeowners indicated that, before the installation of this borehole, their basement flooded every spring as water flowed from the Onondaga bedrock into their basement. This dewatering well drains water from the base of the Onondaga to the top of the more permeable Camillus Shale. This and several other dewatering wells apparently alleviate seasonal basement flooding in the Akron area. A small amount of water was draining from the base of the Onondaga Limestone during the October 1994 borehole-camera survey, when ground-water levels are generally lowest. The presence of excessive amounts of water in the spring, when ground-water levels are highest, suggests a seasonal pattern of water movement along the Onondaga/Akron bedding plane in this area.
Wells 942 and 943 - No significant flow along bedding-plane fractures was observed or detected by borehole geophysical methods in wells north and east of the limestone quarry, even though Staubitz and Miller (1987) observed in their 1984-86 study that the daily discharge from bedrock in the older, southern part of the quarry was, on average, $3.5 \mathrm{Mgal} / \mathrm{d}$. Lack of visual or measured flow in the logged wells may indicate that flow along bedding-plane fractures in the Akron area occurs along discrete zones within the bedding planes or originates from a deeper source. The quarry floor is at least $50 \mathrm{ft}$ above the Onondaga/Akron contact, but the water in the older part of the quarry may be discharging from the contact between the Moorehouse member (little chert) and Clarence member (much chert) of the Onondaga Limestone (table1).

\section{Near-vertical Fractures}

Steeply dipping fractures can affect the general direction of ground-water flow. Square-array resistivity soundings were made to detect the orientation of any near-vertical fractures in the bedrock near the Akron municipal well. (Apparent-resistivity data are given in table 2.) The four smallest array sizes (11.6-, 16.4-, 23.3-, and 32.8-ft squares) provided data on the shallow unconsolidated deposits and were not analyzed, but the 46.2- and 65.6-ft squares represent apparent-resistivity measurements of the subsurface that included the unconsolidated deposits and the Onondaga Limestone (figs. 6A, 6B). These measurements, plotted on polar-coordinate graphs, indicate a small resistivity peak trending at azimuth $345^{\circ}$; this trend was interpreted as a weakly developed, steeply dipping fracture(s) in the Onondaga Limestone with a strike of azimuth $75^{\circ}$. (Fractures are perpendicutar to the trend of maximum apparent resistivity.)

The increased resistivity values in the 92.8 - $\mathrm{ft}$ and 115.8-ft array squares (table 2) indicate that the apparent-resistivity measurements represent all units down through the Akron-Bertie; decreased apparent resistivity values would have indicated that the measurements had penetrated the Camillus Shale because shale has lower resistivity properties than limestone. Polar coordinate plots of apparent-resistivity measurements for these two squares (figs. 6C, 6D) indicate a well-developed resistivity peak trending at azimuth $000^{\circ}$. This trend is interpreted as a well-developed, steeply dipping, fracture within the Akron-Bertie unit with a strike of azimuth $090^{\circ}$. 


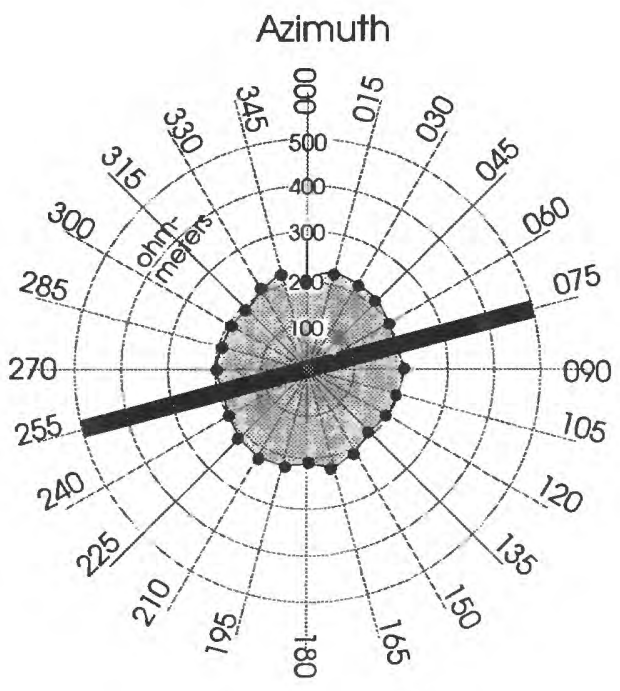

Square $=46.2$ feet

A

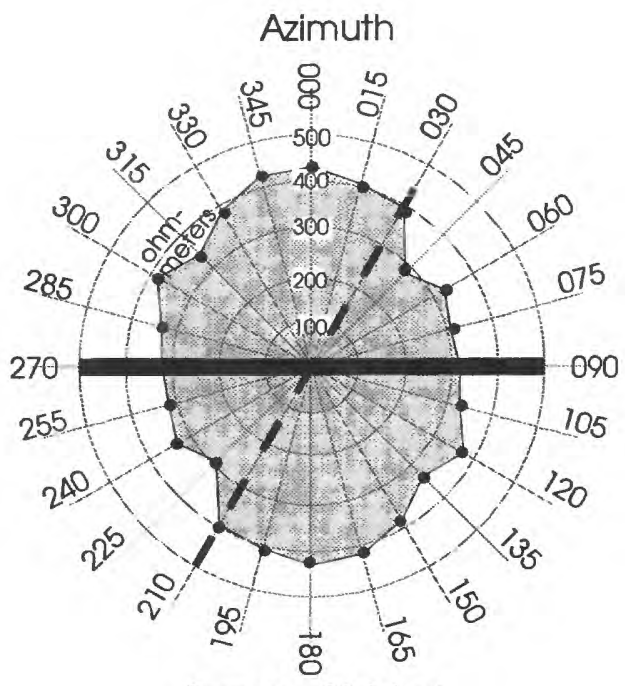

Square $=92.8$ feet

0

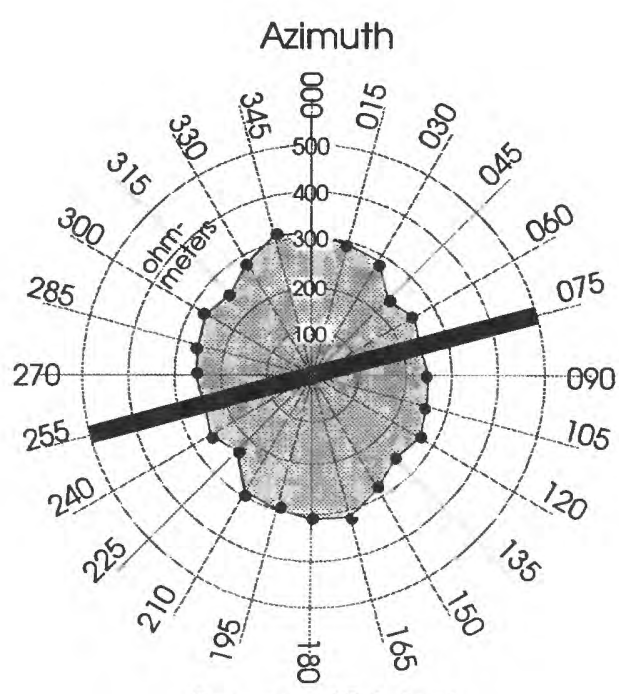

Square $=65.6$ feet

$\mathrm{B}$

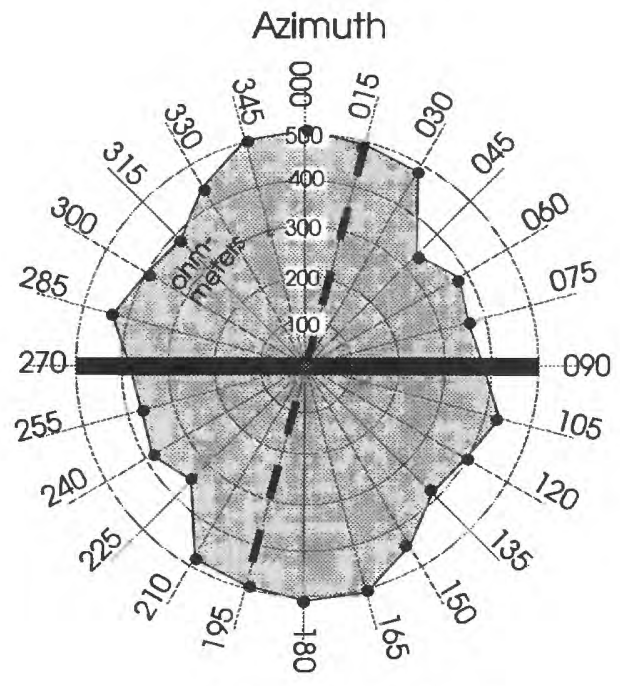

Square $=115.8$ feet

D

\section{EXPLANATION}

030

COMPASS AZIMUTH, in degrees

DATA POINT - indicates apparent resistivity of bedrock at corresponding azimuthal direction

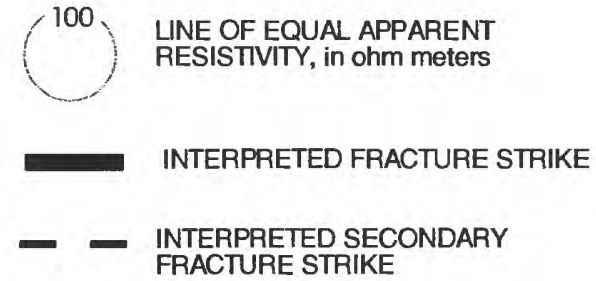
FRACTURE STRIKE

Figure 6. Square-array apparent resistivity plotted against azimuth for squares of: (A) 46.2 feet, (B) 65.6 feet, (C) 98.2 feet, (D) 115.8 feet, measured near Village of Akron's municipal well, Erie County, N.Y. (Site location is shown in fig. 5.) 
Table 2. Azimuthal apparent-resisitivity measurements made near the Village of Akron's municipal well field, Erie County, N. Y.

\begin{tabular}{|c|c|c|c|c|c|c|c|c|c|c|c|c|c|}
\hline \multirow{2}{*}{$\begin{array}{c}\text { Size of } \\
\text { square } \\
\text { (feet) }\end{array}$} & \multirow{2}{*}{$\begin{array}{c}\text { Geometric } \\
\text { mean }\end{array}$} & \multicolumn{12}{|c|}{ Azimuthal pparent resistivity, in ohm-meters } \\
\hline & & $0^{\circ}$ & $15^{\circ}$ & $30^{\circ}$ & $45^{\circ}$ & $60^{\circ}$ & $75^{\circ}$ & $90^{\circ}$ & $105^{\circ}$ & $120^{\circ}$ & $135^{\circ}$ & $150^{\circ}$ & $165^{\circ}$ \\
\hline 11.6 & 105 & $\overline{73}$ & $\overline{78}$ & 80 & 308 & 87 & 143 & 82 & $\overline{78}$ & $\overline{776}$ & 104 & 103 & 197 \\
\hline 16.4 & 107 & 83 & 88 & 91 & 291 & 105 & 113 & 94 & 90 & 87 & 98 & 101 & 130 \\
\hline 23.3 & 119 & 109 & 115 & 115 & 220 & 123 & 119 & 113 & 107 & 108 & 104 & 111 & 118 \\
\hline 32.8 & 153 & 150 & 155 & 158 & 202 & 159 & 150 & 146 & 143 & 142 & 140 & 145 & 156 \\
\hline 46.2 & 202 & 213 & 217 & 217 & 209 & 196 & 188 & 197 & 192 & 192 & 185 & 204 & 220 \\
\hline 65.6 & 270 & 309 & 298 & 289 & 230 & 254 & 242 & 253 & 258 & 268 & 252 & 282 & 314 \\
\hline 92.8 & 359 & 430 & 408 & 396 & 288 & 332 & 312 & 319 & 333 & 378 & 338 & 384 & 423 \\
\hline 115.8 & 424 & 508 & 493 & 483 & 346 & 392 & 365 & 380 & 433 & 399 & 385 & 447 & 504 \\
\hline
\end{tabular}

Results of the square-array analyses closely agree with those joint sets of greatest prominence (azimuths $075^{\circ}$ and $090^{\circ}$ ) shown for the study area in a bedrock-joint (fracture) map of New York (Isachsen and McKendree, 1977). Predominant bedrock joint sets that trend at azimuth $075^{\circ}$ in the Onondaga Limestone in Erie County were also reported by Goldberg-Zoino Associates (1984). The Onondaga Escarpment itself also trends at azimuth $075^{\circ}$ in Erie County and western Genesee County.

Joint measurements were made during this study at the Akron Gorge in the Village of Akron for comparison with interpretations of the square-array data. The trend of predominant joint sets in the Onondaga Limestone was between azimuth $064^{\circ}$ and $074^{\circ}$, and that in the Akron-Bertie unit was between azimuth $080^{\circ}$ and $088^{\circ}$. The unconformity between the Onondaga Limestone and underlying Akron Limestone might help explain the small difference in orientation of near-vertical fractures in those two units, in that the two fracture orientations may have been induced by differing directions of stress during the lower Devonian and upper Silurian times.

The stronger resistivity response in the AkronBertie unit than in the Onondaga suggests the presence of well-developed, near-vertical fractures that could affect the hydraulic properties of the Akron-Bertie unit. The weak, nearly homogeneous resistivity response in the Onondaga Limestone suggest that either (1) the Onondaga response is masked by the unconsolidated deposits, or (2) major near-vertical fractures are few and would have only a minor effect on ground-water flow in this unit.

\section{Weathered and Fractured Top of Bedrock}

The upper 10 to 15 feet of bedrock in the Akron area, regardless of lithology, is moderately fractured and weathered from the past effects of glaciation, postglacial uplift, and subsequent physical and chemical actions of water moving through these fractures. The bedrock surface south of New York State Route 5 represents the upper part of the Onondaga Limestone and is highly weathered and contains karstlike features-sinkholes, disappearing streams, and dissolution channels. This highly fractured and solutioned zone probably extends to depths of more than $15 \mathrm{ft}$. Preferential movement of runoff probably caused the "channel-like depression area," which contains a series of sinkholes (fig. 2) and a solution-enhanced zone of ground-water movement, as described by Staubitz and Miller (1987).

The bedrock surface in the northern part of the study area consists of the lower, cherty member of the Onondaga Limestone (Clarence member, table 1), which underlies the unconsolidated deposits. The high chert content (greater than 50 percent) of the Clarence member impedes the effects of weathering and results in a thinner weathered and fractured zone than found in the south-typically less than $10 \mathrm{ft}$ from the top of bedrock. Borehole-camera logs of wells along Scotland Road and the northern part of Crittenden Road (fig. 2), and observations of vertical fractures at rock exposures along the Onondaga Escarpment, also indicate only a thin weathered zone in the Clarence member. Results of the square-array study (described above) also suggest a poorly developed system of fractures in the upper bedrock near the municipal well. 
Flow conditions through the upper $20 \mathrm{ft}$ of bedrock (Clarence member) at the Akron municipal well were noted in March 1995, during the testing of a new pump. The monitoring well (well 940), $25 \mathrm{ft}$ from the municipal well, was measured for water-level declines as the new pump was being tested. The monitoring well is $20 \mathrm{ft}$ shallower than the municipal well and does not penetrate the Onondaga/Akron bedding plane; therefore, the water-level response in the monitoring well would reflect the degree of connection among fractures in the upper fractured and weathered bedrock between the two wells.

Water levels in the monitoring well responded slowly to changes in the pumping rate (from $55 \mathrm{gal} /$ $\mathrm{min}$, to $75 \mathrm{gal} / \mathrm{min}$ and, finally, $100 \mathrm{gal} / \mathrm{min}$ during the 1.5-hour test), and total drawdown at the monitoring well was nearly $6 \mathrm{ft}$ after $90 \mathrm{~min}$. Total drawdown in the municipal well was about $24 \mathrm{ft}$, but the draw-down data from that well were too limited to yield reliable hydraulic values for the aquifer. Results did show, however, that the weathered upper part of bedrock provides some water to the Akron municipal well.

\section{Well-Yield Characteristics}

The Akron municipal well (12-in. diameter) was drilled in 1969 to a depth of $70 \mathrm{ft}$. The drilling log for this well indicates that the unconsolidated deposits are $29 \mathrm{ft}$ thick and that the Onondaga Limestone extends from $29 \mathrm{ft}$ to $70 \mathrm{ft}$ below land surface. The reported yield exceeded $200 \mathrm{gal} / \mathrm{min}$ when this well was initially tested in 1969 (Daniel Huff, written commun., 1995).

Drillers' records from more than 60 domestic wells within a 2-mi radius of the Akron municipal well indicate that the average depth for a standard 6-in. domestic water-supply well is about $73 \mathrm{ft}$, and the average yield is about $15 \mathrm{gal} / \mathrm{min}$. (Locations of waterproduction zones at the domestic wells were not identified in the well reports, and the availability of well-completion depths varies form one locality to the next; the informal well-yield data provided by the driller are also variable and seasonally dependent; therefore, most water-producing zones are assumed to be in the upper, weathered and fractured-bedrock part of each drillhole and represent the average well yield from this zone.) Although the 12-in diameter of the Akron municipal well could account for some increase in the reported well yield, only one domestic well within the 2-mi radius had a reported yield greater than $100 \mathrm{gal} / \mathrm{min}$. Results of this domestic-well survey indicate that the Akron municipal well has a relatively high yield for the Akron area.

The specific capacity of a well (in gallons per foot of drawdown, gal/ft) is a measure of the wells' productivity or yield. The company that maintains and services the Akron municipal well indicated that the specific capacity was $12.4 \mathrm{gal} / \mathrm{ft}$ in September 1969 , but had declined to about $5.4 \mathrm{gal} / \mathrm{ft}$ by December 1993 . This loss in productivity may be due, in part, to clogging of the fractures by clay or residue from the limestone matrix as water moves through the fractures. Decreases in well productivity from increased pumping or reduced formation permeability are not unusual (Karanjac, 1972). Pumping rates greater than $100 \mathrm{gal} / \mathrm{min}$ have caused turbidity increases at the municipal well, as noted in the wellmaintenance reports (Daniel Huff, written commun., 1995). The increased turbidity and decreased yield over time could prevent the well from sustaining its current pumping rate (about $100 \mathrm{gal} / \mathrm{min}$ ) if clogging of the bedrock fractures continues to increase.

\section{Ground-Water Quality}

Water-quality data for the Akron municipal well (provided by the Village of Akron) indicate that the water pumped from this well meets New York State drinking-water standards. The area surrounding the municipal well is agricultural and low-density residential, and well-water analyses have not detected herbicides or pesticides.

Median concentrations of major cations and anions in samples from the Akron well were compared with those in samples from wells tapping the Onondaga Limestone and unconsolidated deposits in the surrounding area. A Piper diagram representing 53 water samples collected by Miller and Staubitz during 1982-84 (23 from bedrock, 30 from unconsolidated deposits), and median values of water from the Akron municipal well, are shown in figure 7. The median values for the Akron well samples reflect the chemical characteristics of Onondaga Limestone water; the high sodium and chloride concentrations in water from unconsolidated deposits (in the lower triangles of the plot) could be attributed to road salt.

Stiff diagrams depict water-quality data in a different way; five Stiff diagrams (fig. 8) indicate the median cation/anion concentrations of 9 water samples form the Akron municipal well, 23 samples from other wells completed in the Onondaga Limestone, 30 samples from wells completed in the 


\section{EXPLANATION}
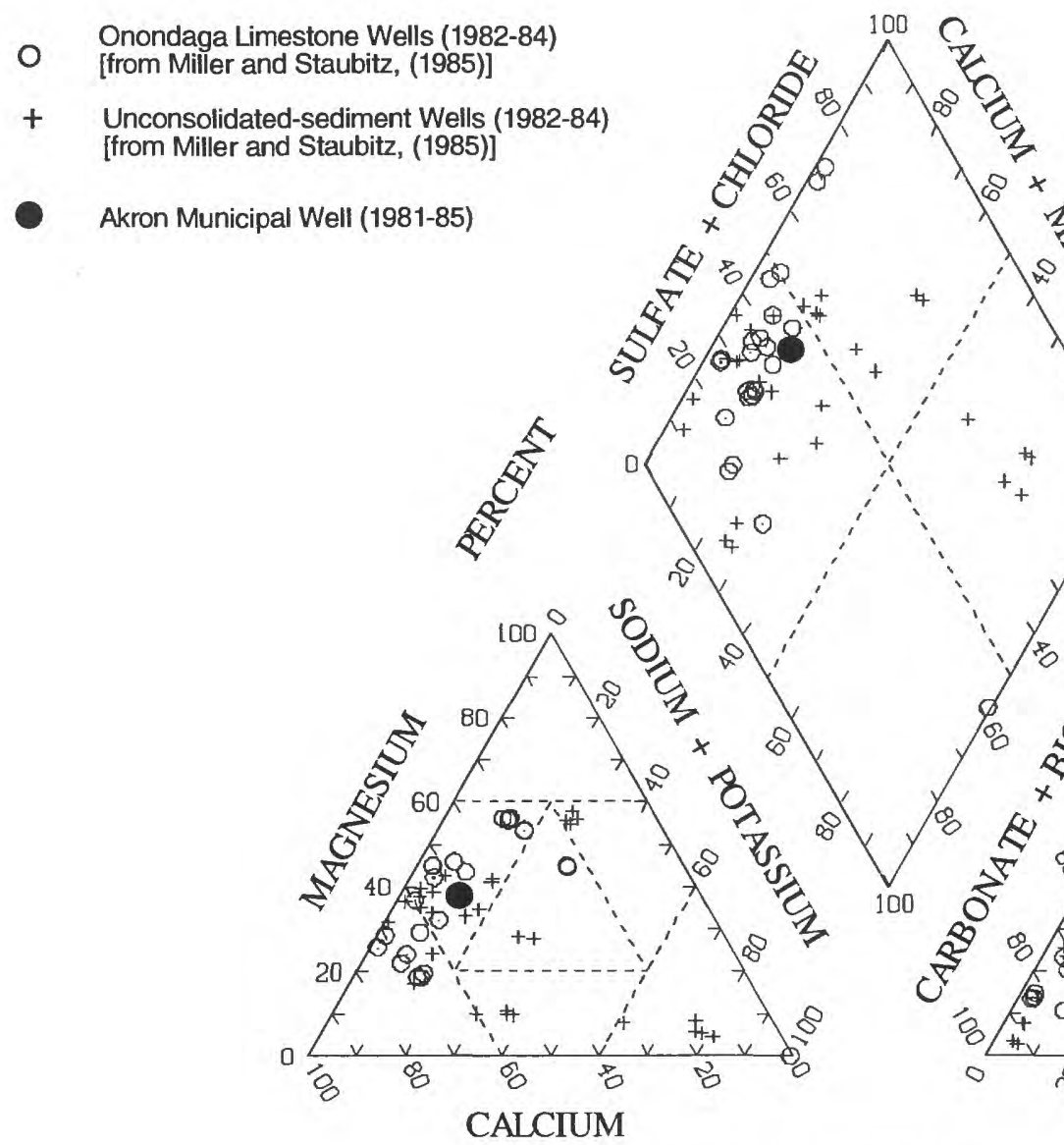

PERCENT OF TOTAL MILLIEQUIVALENTS PER LITER

Figure 7. Piper diagram showing chemical characteristics of water from Akron, N.Y. municipal well in relation to water from the Onondaga Limestone and unconsolidated deposits in surrounding area, as compiled by Miller and Staubitz (1985).

unconsolidated aquifer, 2 samples from wells completed in the Akron Dolomite-Bertie Limestone unit; and 1 sample from a well completed in the Camillus Shale. The Stiff diagram for the Akron municipal well is similar to that for the 23 other wells completed in the Onondaga Limestone, in that calcium and bicarbonate have the highest milliequivalent concentrations, indicating a limestone-derived water source. Although the number of samples from the Akron-Bertie unit and the Camillus Shale is small, they indicate a calcium-sulfate type water and a gypsum-derived water source.

The Stiff diagram for water from the unconsolidated aquifer differs markedly from those for the bedrock aquifer diagrams-it indicates an admixture of magnesium with bicarbonate water and relatively high concentrations of sodium and chloride. The high bicarbonate concentrations probably indicate that the unconsolidated deposits contain pieces of Onondaga Limestone, Akron Dolomite, and Bertie Limestone, which are being dissolved by ground water as it moves through the deposits. The elevated sodium and chloride concentrations suggest contamination by runoff containing road salt.

Sodium- and chloride-concentration data from the Akron well were examined to determine whether roadsalt-laden runoff could be entering the shallow bedrock aquifer. Leonard and Ward (1962) used the mass ratio of sodium to chloride to determine the source of salinity in a bedrock aquifer, and Richter and Kreitler (1991) indicated that sources of salinity can be identified by the ratios of specific chemical constituents such as calcium, magnesium, potassium, sodium, sulfate, and chloride. Halite (road salt) has a sodium to chloride ratio of 0.648 (by mass), and a ratio of less than 0.600 indicates a deep brine source, thus, a ratio between 0.630 and 0.650 is probably indicates road-salt contamination. The sodium-to-chloride ratios for water samples from the municipal well are given in table 3. 

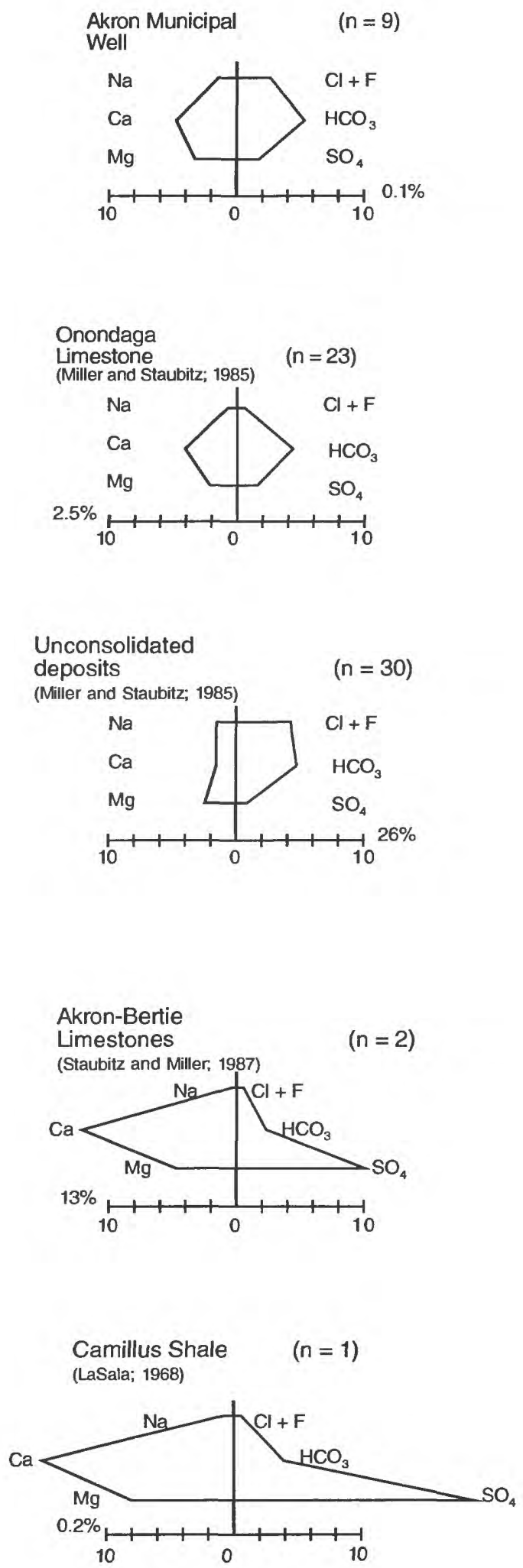

Figure 8. Stiff diagrams showing median anion and cation concentrations (in milliequivalents per liter) in water from Akron municipal well, Erie County, N.Y., and reported results from several other aquifers in the Akron area.

\section{EXPLANATION}

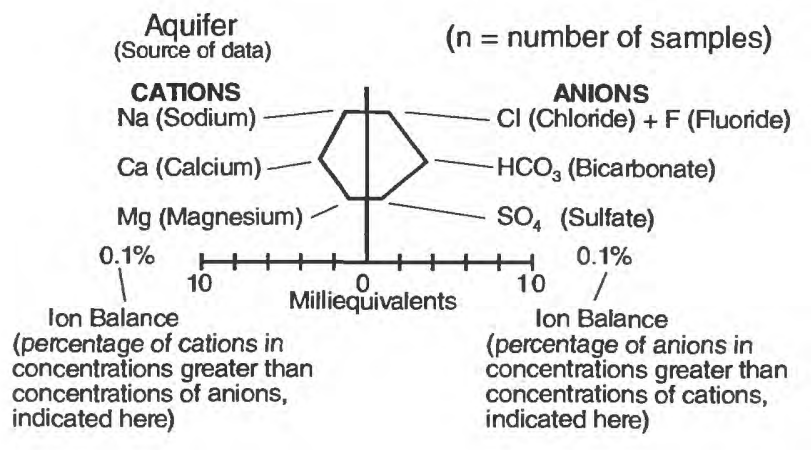

The sodium-to-chloride mass ratio of all water samples collected from the Akron municipal well between February 1981 and October 1985 was less than 0.600 and averaged 0.309 . The winter samples averaged 0.294 , and the late-summer samples averaged 0.324 . These ratios suggest that water of low salinity, probably derived from a highly dilute Appalachian-basin brine, is slowly moving updip (northward) along the Onondaga/Akron contact. The process of brine moving updip along bedding-plane fractures elsewhere in western New York has been documented by Siegel and others (1990) and Dr. William Goodman (University of Rochester, oral commun., 1995). Determination of the source and extent of this brine was beyond the scope of this project, however, because the salinity of the pumped water is low and greatly diluted by large quantities of freshwater moving downdip from the Onondaga Escarpment along this beddingplane fracture, and is not a threat at present.

Table 3. Ratio of sodium and chloride (by mass) in water samples from the Akron municipal well, Erie County, N.Y., February 1981 through October 1985.

[mg/L, milligrams per liter]

\begin{tabular}{lccc}
\hline \multicolumn{1}{c}{ Date } & \multicolumn{2}{c}{ Concentration (mg/L) } & $\begin{array}{c}\text { Sodium-to- } \\
\text { chloride ratio } \\
\text { (mass) }\end{array}$ \\
\cline { 2 - 4 } & Sodium & Chloride & (m.5 \\
\hline February 21, 1981 & 26.1 & 72.5 & 0.360 \\
October 19, 1981 & 29.0 & 92.5 & .314 \\
March 10, 1982 & 29.1 & 77.5 & .375 \\
September 27, 1982 & 37.4 & 125. & .299 \\
February 14, 1983 & 35.1 & 150. & .234 \\
September 13, 1983 & 30.5 & 82.5 & .370 \\
February 13, 1985 & 41.6 & 200. & .208 \\
October 17, 1985 & 33.0 & 105. & .314 \\
\hline
\end{tabular}




\section{Ground-Water/Surface-Water Interaction}

The surface-water reservoir and the municipal well that supply water to the Village of Akron are within the Murder Creek watershed (fig. 2). The upper $2.5 \mathrm{mi}^{2}$ of the Murder Creek drainage is impounded and serves as the contributing watershed to the Akron surface-water reservoir. Streamflow measurements were made under low-flow conditions on September 12 and 13, 1994, to determine the amount of gain or loss of water along Murder Creek and selected tributaries where they flow over the Onondaga Limestone. Ten sites were chosen between the village of Corfu, in the south (fig. 2), to the stream-gaging station north of the Village of Akron, but only six sites had measurable flow. Results (table 4) indicate that the unit yield (flow per square mile) increases nearly eightfold in the $11 \mathrm{mi}$ from Corfu to the Onondaga Escarpmentfrom $8.28 \times 10^{-3}\left(\mathrm{ft}^{3} / \mathrm{s}\right) / \mathrm{mi}^{2}$ to $3.08 \times 10^{-2}\left(\mathrm{ft}^{3} / \mathrm{s}\right) /$ $\mathrm{mi}^{2}$ at Akron, then sharply increases (by an order of magnitude) to $1.0 \times 10^{-1}\left(\mathrm{ft}^{3} / \mathrm{s}\right) / \mathrm{mi}^{2}$ at the USGS gaging station $1.5 \mathrm{mi}$ downstream. The large downstream increase $\left(2.69 \times 10^{-1}\left(\mathrm{ft}^{3} / \mathrm{s}\right) / \mathrm{mi}^{2}\right)$ is due to: (1) industrial cooling-water discharges to Cedar Creek from the abandoned gypsum mines, and (2) discharge from the Village of Akron sewagetreatment plant to Murder Creek. Subtracting these supplementary flows from the total measured flow of Murder Creek at the gaging station reduces the unit yield to $2.82 \times 10^{-2}\left(\mathrm{ft}^{3} / \mathrm{s}\right) / \mathrm{mi}^{2}$, which indicates ground-water discharge similar to that measured just upstream of the escarpment. The consistent increase in unit yield of Murder Creek south of the escarpment indicates that the creek and its tributaries are being recharged from the bedrock. Even though no measurements of streamflow were made near the municipal well in Murder Creek because the gradient is flat and the flow sluggish, the overall gain in streamflow in this section (between sites 2 and 4 in fig. 2) suggests that the Akron municipal well is not causing induced infiltration from Murder Creek. Gabbey Brook, which is east of the municipal well and in a similar geographic setting, has a unit yield $3.05 \times 10^{-2}\left(\mathrm{ft}^{3} / \mathrm{s}\right) / \mathrm{mi}^{2}$, similar to that between sites 4 and 2 .

Table 4. Results of streamflow measurements on Murder Creek and selected tributaries, Erie County, N.Y., September 12-13, 1994

[ $\mathrm{mi}^{2}$, square mile. Dashes (--) indicate no data. Location is shown in fig. 2.]

\begin{tabular}{|c|c|c|c|c|}
\hline \multirow[b]{2}{*}{$\begin{array}{c}\text { Site } \\
\text { number }\end{array}$} & \multirow[b]{2}{*}{ Site name } & \multirow[b]{2}{*}{$\begin{array}{c}\text { Drainage } \\
\text { area } \\
\left(\mathrm{mi}^{2)}\right.\end{array}$} & \multicolumn{2}{|c|}{ Discharge } \\
\hline & & & $\begin{array}{l}\text { Cubic feet } \\
\text { per } \\
\text { second }\end{array}$ & $\begin{array}{l}\text { Cubic feet per } \\
\text { second per } \\
\text { square mile }\end{array}$ \\
\hline 1 & Murder Creek at Corfu & 32.5 & 0.269 & $8.28 \times 10^{-3}$ \\
\hline \multirow[t]{2}{*}{2} & Murder Creek near Pembroke & 41.1 & .408 & $9.93 \times 10^{-3}$ \\
\hline & (site 2 minus site 1 ) & 8.60 & .139 & $1.62 \times 10^{-2}$ \\
\hline 3 & Gabbey Brook at Pembroke Station & 4.36 & .133 & $3.05 \times 10^{-2}$ \\
\hline \multirow[t]{2}{*}{4} & Murder Creek at Akron & $\underline{53.3}$ & .784 & $1.47 \times 10^{-2}$ \\
\hline & (site 4 minus site 2 ) & 12.2 & .376 & $3.08 \times 10^{-2}$ \\
\hline 5 & Sewage Treatment Plant Discharge (estimated) & --- & .464 & --- \\
\hline 6 & Cedar Brook at Akron (cooling-water discharges) & 1.28 & 3.58 & 2.80 \\
\hline 7 & Murder Creek near Akron (Station 04217750) & 56.3 & 5.63 & $1.0 \times 10^{-1}$ \\
\hline \multirow[t]{2}{*}{$7 \mathrm{a}$} & Murder Creek near Akron (minus supplementary flows) & $\underline{56.3}$ & $\underline{1.59}$ & $\underline{2.82 \times 10^{-1}}$ \\
\hline & (site 7a minus site 4) & 3.0 & .806 & $2.69 \times 10^{-1}$ \\
\hline
\end{tabular}

${ }^{1}$ Drainage area of Murder Creek does not include the $2.5 \mathrm{mi}^{2}$ headwater drainage area of Murder Creek, which supplies the Akron water-supply reservoir 


\section{Ground-Water Flow}

Ground water in bedrock in the Akron area moves primarily along five zones: (1) the beddingplane fracture between the Camillus Shale and Bertie Limestone, (2) the bedding-plane fracture between the Bertie Limestone and Akron Dolomite, (3) the bedding-plane fracture along the regional unconformity between the Akron Dolomite and Onondaga Limestone, (4) the bedding plane between the top of the Clarence and the bottom of the Moorehouse members of the Onondaga Limestone, and (5) within the weathered and highly fractured upper part of the bedrock (see table 1 ).

A conceptual diagram of ground-water flow in bedrock in the Akron area is presented in figure 9. Ground-water flow in the bedding-plane fracture between the Camillus Shale and the Bertie Limestone is greatest near the Onondaga Escarpment and within the old gypsum mines because dissolution of mineral salts (gypsum) has increased the permeability in the upper Camillus Formation. Permeability along this bedding plane further south is lower because the weight of rock has reduced fracture openings. The abandoned gypsum mines below the Bertie-Camillus contact are currently being used for process-cooling waters, and several industries together remove as much as $4.0 \mathrm{Mgal} / \mathrm{d}$, of which half is reinjected to the mines, and the remainder is discharged to Cedar Creek. This cycling of water could increase the dissolution of gypsum salts in the abandoned mine by inducing infiltration of fresher water that is undersaturated with gypsum salts.

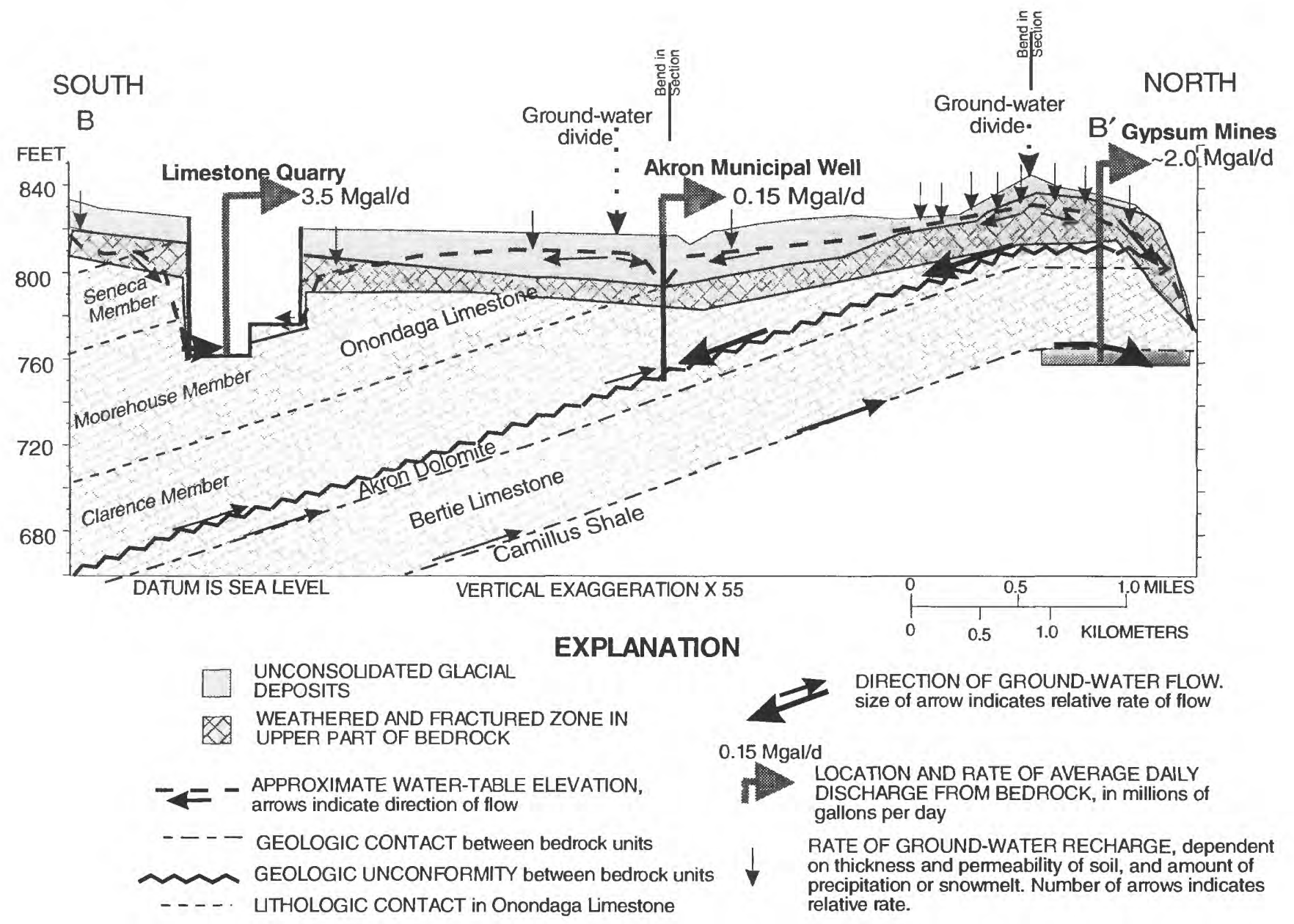

Figure 9. North-south geologic section east of Critenden/Scotland Roads showing ground-water flowpaths and the three major bedrock discharge locations in the Akron study area. (Location of section is shown in fig. 10.) 
Water movement probably also occurs at the bedding-plane fracture between the Bertie Limestone and the Akron Dolomite. Ground-water flow is greatest near the escarpment, where the density of fractures is greatest, but ground-water movement along this contact is probably much less than that along the Camillus-Bertie contact because it is not an unconformity and because bedding-plane fractures are less likely to form when adjacent units have a similar composition (less cherty limestone-dolomite) than that of the Camillus-Bertie (shale-limestone) contact.

The bedding-plane fracture at the Onondaga Limestone/Akron Dolomite contact is a regional unconformity and is probably the zone of greatest ground-water movement in the Akron area. At the Onondaga Escarpment, this bedding plane is near land surface, where precipitation directly recharges the Onondaga Limestone. The pumping of the Akron municipal well causes water that infiltrates near the escarpment north and east of the well to move along the bedding plane toward the well. Movement from the northwest is cut off by the Akron Gorge, and infiltration of precipitation south of the municipal well is impeded by the increased thickness of relatively impermeable soils that overlie the bedrock and the increasing thickness of bedrock that isolates the Onondaga-Akron contact from surface infiltration.

The bedding plane between the Clarence and Moorehouse members of the Onondaga Limestone is a possible water-bearing zone. Staubitz and Miller (1987) found that the bedding plane had been widened in quarries and along the Onondaga Escarpment by the dissolution process through preferential horizontal movement of water between the cherty Clarence member and the less-cherty Moorehouse member of the Onondaga Limestone. A large void near the bedrock surface at the Akron municipal well, detected in the borehole-video camera log could be the physical expression of this contact.

The uppermost flow system in the Akron area is the highly weathered and fractured upper bedrock surface, and the fracturing and weathering are greatest near the escarpment, where the soil cover is thinnest. A ground-water divide less than $0.5 \mathrm{mi}$. south of the escarpment (fig. 9) separates northward ground-water flow, which may appear as springs at the base of the escarpment, from southward flow that moves (a) through the moderately weathered, cherty, upper bedrock and (b) to bedding-plane fractures that dip to the south. Another ground-water divide in the upper bedrock was located by Staubitz and Miller (1987) roughly parallel to New York State Route 5, west of Crittenden Road (fig. 10). This divide separates ground-water flow that moves south toward the stone quarry and the channel-like depression area south of Route 5 (fig. 2) from ground-water flow that moves north toward the Akron Gorge and the Village of Akron. The two ground-water divides (fig. 10) form the limits of the shallow-bedrock flow system that might supply water to the Akron municipal well.

The primary water-bearing zones tapped by the Akron municipal well appear to be the OnondagaAkron bedding-plane fracture and the upper, weathered bedrock. The land-surface area contributing recharge to these two zones is difficult to characterize because the percent contribution of water from each zone is unknown, and fracture patterns in the bedrock have not been fully delineated, among many other factors. The areal extent of the contributing area can be approximated, however, from an average recharge rate and a projected annual rate of withdrawal from the Akron municipal well, as follows:.

Recharge rate. - Most soils in the study area are low permeability clay and silt that overlie a layer of dense, clayey till. A recharge rate of $10 \mathrm{in} / \mathrm{yr}$ was chosen on the basis of similar fine-grained glacial sediments in the Niagara Falls area 15 miles to the northwest (fig. 1), (E. C. Jordan Co., 1985; Conestoga-Rovers and Associates and WoodwardClyde Consultants, 1990).

Withdrawal rate. - The maximum monthly pumpage from December 1994 through November 1995 occurred in May 1995 (2.6 Mgal/d) (Daniel Huff, written commun., 1996).

Calculation. - Projecting this maximum monthly pumpage to an entire year results in a volume of 31 Mgal or $4.1 \times 10^{6} \mathrm{ft}^{3}$. Dividing this volume by the projected annual recharge of $0.83 \mathrm{ft}$ (10 in.) yields an area of about $4.9 \times 10^{6} \mathrm{ft}^{2}$, or about 115 acres. The relative size of the area is shown in figure 10. Allocation of the contributing area to each zone tapped by the Akron municipal well would be difficult in this fractured-rock environment and was beyond the scope of this study. 


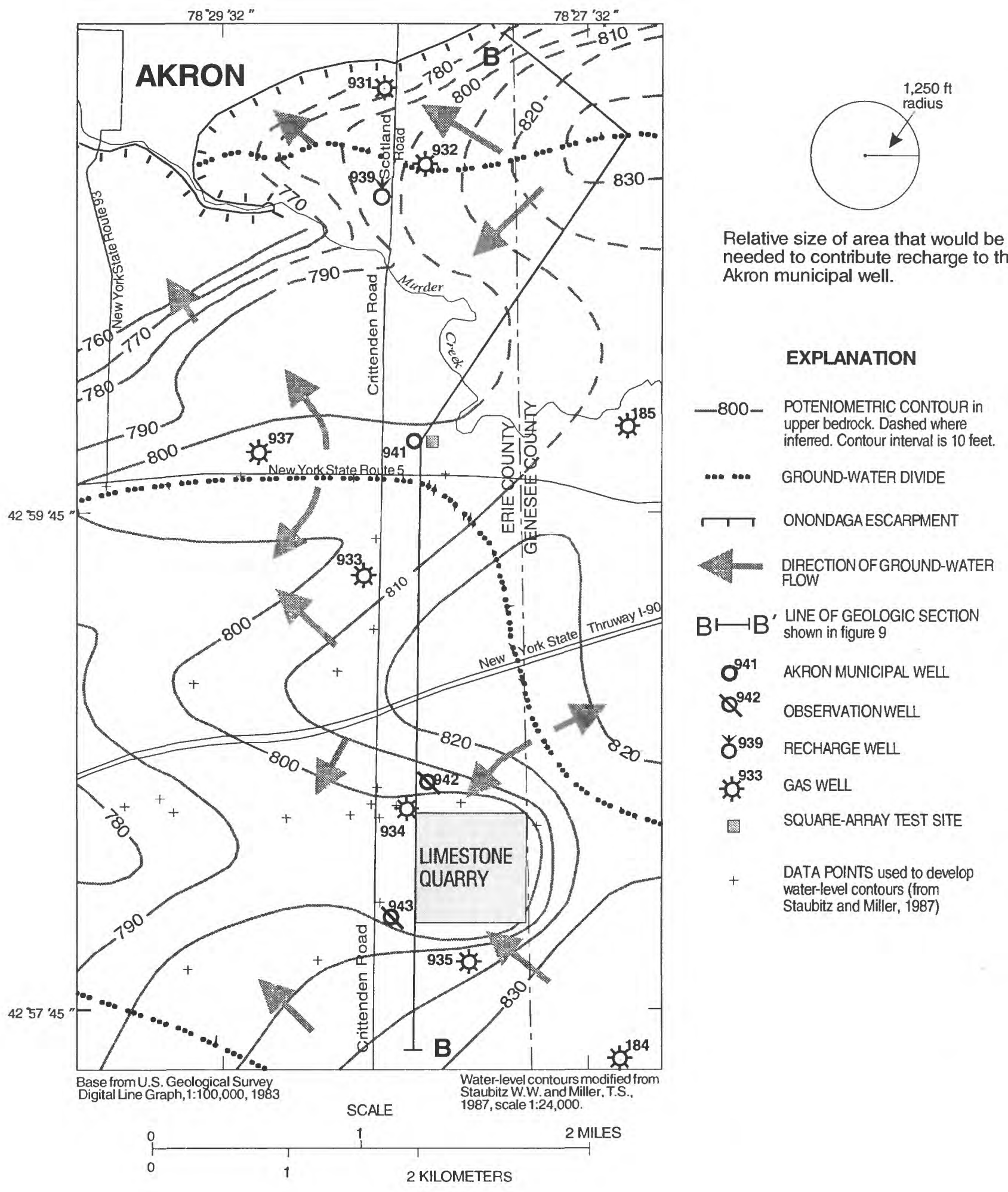

Figure 10. Potentiometric-surface altitude in upper bedrock and locations of ground-water divides north and south of Akron municipal well, Erie County, N.Y. 


\section{SUMMARY AND CONCLUSIONS}

The Village of Akron water system uses a municipal well to supplement its surface-water supply, but the ground water is from several sources, and its continued yield and protection from contamination are of concern. The contact between the Onondaga Limestone and the underlying Akron Dolomite-a regional unconformity and the location of a major bedding-plane fracture, is a primary pathway for ground-water flow in the Akron area. The Akron municipal well has a current yield of about $100 \mathrm{gal} / \mathrm{min}$; in contrast, the average yield of about 60 domestic wells surrounding the municipal well is about $15 \mathrm{gal} / \mathrm{min}$.

The current pumping rate of the municipal well is only half the rate obtained when the well was drilled in 1969 because bedrock fractures have become clogged with clay and solution residue from the Onondaga Limestone and Akron Dolomite. This could, in time, decrease the well's ability to adequately supplement the surface-water supply.

Results of water-quality analyses indicate that water recharging the municipal well flows mainly downdip (southward), from the Onondaga Escarpment, along the Onondaga Limestone and Akron Dolomite bedding-plane fracture, and is supplemented by a minor contribution from the upper, weathered Onondaga bedrock surface. Even though Murder Creek is just $1,000 \mathrm{ft}$ east of the municipal well, streamflow measurements along the creek indicate that ground water is discharging to the Murder Creek; thus, only limited, if any, recharge from Murder Creek is flowing to the municipal well.

The area that recharges the Onondaga/Akron bedding-plane fracture is north and east of the municipal well, where soils are thin, and this bedding-plane fracture is near land surface. The well is also recharged from the upper, weathered, and fractured bedrock surface and by water from nearvertical fractures that are oriented along azimuth $075^{\circ}$, as calculated from results of a square-array resistivity survey. Although the municipal well's ground-water-contributing area could not be delineated, owing to the complexity of the bedrock flow system, infiltration of precipitation over an area of about 115 acres could supply enough water to maintain the current yield of the municipal well, as calculated from past pumping rates and an estimated recharge rate of about $10 \mathrm{in} / \mathrm{yr}$.
Water-quality data indicate that a small amount of brackish water moves updip from the south along the Onondaga/Akron bedding-plane fracture. The low sodium-to-chloride ratio identifies this water as recharge from deep basin brines, but this water constitutes only a small percentage of the water pumped from the municipal well and is not a threat. Runoff containing road salt does not appear to affect water from this well.

The predominant land use in the area surrounding the municipal well is agricultural and low-density residential; therefore, protection of this area from exposure to fertilizers, pesticides, and other contaminants associated with farming and development is critical to the protection of the aquifer.

\section{REFERENCES CITED}

Cassa, M. R., 1980, Stratigraphy and petrology of the Onondaga Limestone (Middle Devonian), eastern Lake Erie region of New York, Pennsylvania, and Ontario: Binghamton, N.Y., State University of New York at Binghamton, unpublished master's thesis, $108 \mathrm{p}$.

Compton, R. R., 1985, Geology in the field: New York, John Wiley, $115 \mathrm{p}$.

Conestoga-Rovers and Associates and Woodward-Clyde Consultants, 1990, Remedial investigation final report, 102nd Street landfill site, Niagara Falls, New York: Niagara Falls, N.Y., Conestoga-Rovers and Associates, $60 \mathrm{p}$.

Dunn Corporation, 1992, Hydrogeologic report for Akzo ash processing project: Albany, N.Y., prepared for Akzo Salt, 44 p.

E. C. Jordan Co., 1985, Love Canal remedial project, Love Canal long-term monitoring program design: Portland, Me., E. C. Jordan Co., 163 p.

Goldberg-Zoino Associates, 1984, Hydrogeologic evaluation of Camillus Shale aquifer in Southern Clarence, New York: Buffalo, N.Y., Goldberg-Zoino Associates, $155 \mathrm{p}$.

Habberjam, G.M., 1972, The affects of anisotropy on square-array resistivity measurements: Geophysical Prospecting, v. 20, p. 249-266.

Isachsen, Y.W. and McKendree, W.G., 1977, Preliminary brittle structure map of New York, Niagara-Finger Lakes sheet: Albany, N.Y., New York State Science and Museum Map and Chart 31, scale 1:1,000,000.

Keys, W.S., 1990. Borehole geophysics applied to ground water investigations: U. S. Geological Survey Techniques of Water Resources Investigations, Book 2, chap E2, 150 p. 
Karanjac, J., 1972, Well losses due to reduced formation permeability: Ground Water, v. 10, no. 4, p. 42-49.

Lane, J.W., Haeni, F.P., and Watson, W.M., 1995, Use of a Square-array direct-current resistivity method to detect fractures in crystalline bedrock in New Hampshire: Ground Water, v. 33, no. 3, p. 476-485.

LaSala, A. M., 1967, Ground-water resources of the ErieNiagara Basin, New York: Albany, N.Y., New York State Conservation Department, Water-Resources Commission, Basin Planning Report ENB-3, 114 p.

Leonard, A. R., and Ward, P. E., 1962, Use of $\mathrm{Na} / \mathrm{Cl}$ ratios to distinguish oil-field from salt-spring brines in Western Oklahoma: U. S. Geological Survey Professional Paper 450-B, p. B126-B127.

Miller, T. S., and Staubitz, W. W., 1985, Hydrogeologic appraisal of five selected aquifers in Erie County: U. S. Geological Survey Water-Resources Investigations Report 84-4334, 89 p.

Rantz, S. E., and others, 1982, Measurement and computation of streamflow, volume 1, measurement of stage and discharge: U.S. Geological Survey Water-Supply Paper 2175,248 p.
Richter, B. C., and Kreitler, C. W., 1991, Identification of sources of ground-water salinization using geochemical techniques: Austin, Texas, U. S. Environmental Protection Agency, EPA/600/2-91/064, $258 \mathrm{p}$.

Siegel, D. I., Szustakowski, R. J., and Frape, S., 1990, Regional appraisal of brine chemistry in the Albion group sandstones (Silurian) of New York, Pennsylvania, and Ohio: Association of Petroleum Geochemical Explorationists, Bulletin no. 6, p. 66-77.

Staubitz, W. W., and Miller, T.S., 1987, Geology and Hydrology of the Onondaga Aquifer in Eastern Erie County, New York, with emphasis on ground-waterlevel declines since 1982: U. S. Geological Survey Water Resources Investigations Report 86-4317, $44 \mathrm{p}$.

Yager, R. M., and Kappel, W. M., 1987, Characterization of fractures in the Lockport Dolomite, Niagara County, New York, in Khanbilvardi, R. M., and Fillos, J., (eds.), Pollution, risk assessment, and remediation in groundwater systems: Washington, D. C., Scientific Publications Co., p. 149-195. 